\title{
Nordic Pragmatism
}

\section{Sami Pihlström}

\section{OpenEdition \\ Journals}

Electronic version

URL: http://journals.openedition.org/ejpap/945

DOI: 10.4000/ejpap.945

ISSN: 2036-4091

\section{Publisher}

Associazione Pragma

\section{Electronic reference}

Sami Pihlström, « Nordic Pragmatism », European Journal of Pragmatism and American Philosophy [Online], II-1 | 2010, Online since 01 July 2010, connection on 01 May 2019. URL : http:// journals.openedition.org/ejpap/945 ; DOI : 10.4000/ejpap.945

This text was automatically generated on 1 May 2019.

\section{(c) $($ i) $(9)$}

Author retains copyright and grants the European Journal of Pragmatism and American Philosophy right of first publication with the work simultaneously licensed under a Creative Commons AttributionNonCommercial-NoDerivatives 4.0 International License. 


\title{
Nordic Pragmatism
}

\author{
Sami Pihlström
}

\section{AUTHOR'S NOTE}

An early, very brief version of this essay appeared, with the title, "Pragmatism in Scandinavia," in Marika Enwald and Petri Räsänen (eds.), Studia philosophica in honorem Leila Haaparanta (Acta Philosophica Tamperensia 3, Tampere University Press, Tampere, 2004). I am grateful to Torjus Midtgarden for his help with "Norwegian pragmatism," to Rein Vihalemm for a conversation on Estonian philosophy, and to Johan Strang for his inviting me to present a guest lecture on the topic of this paper in the lecture series, "Nordic Society and the History of Modern Philosophy" (Centre for Nordic Studies, University of Helsinki, April 2004). Strang also included one of my papers (Pihlström 2006) on this same topic in Swedish translation in his collection of articles on the influence of various philosophical traditions in Finland and Sweden. Special thanks to Jim Campbell for his help with J. E. Boodin's Swedish origins, to John R. Shook for his commitment to promoting pragmatism worldwide, including Scandinavia, and Henrik Rydenfelt and Jon Olafsson, with whom I started the activities of the Nordic Pragmatism Network in 2008 (for the Network's program, see http://www.nordprag.org). I also thank Leila Haaparanta and Ilkka Niiniluoto for their willingness to promote pragmatism research in Finland. This paper was first published in Sami Pihlström and Henrik Rydenfelt (eds.), Pragmatist Perspectives, Acta Philosophica Fennica 86, Helsinki, The Philosophical Society of Finland, 2009.

\section{Introduction}

1 "Geographical" divisions of philosophy are often misleading - at least if one thinks about the dichotomy between Anglo-American "analytic" and "Continental" philosophy in the twentieth century - but in special contexts it is interesting to consider how certain 
philosophical traditions have spread geographically. The American tradition of pragmatism became hotly debated in Europe early in the twentieth century, with William James as its leading figure and F.C.S.Schiller as its main European (British) representative. As is well known, there is a special variant of "Italian pragmatism," for instance, with tensions between the Jamesian (and Schillerian) pragmatists like Giovanni Papini, on the one side, and those more influenced by Charles S. Peirce, like Mario Calderoni, on the other. (See, e.g., Golino 1955, Gullace 1962, Zanoni 1979, Colella 2005)

Italian pragmatism was so strong that even James himself devoted a brief essay to it (James 1906b). Nothing like that happened, as far as I know, in the Nordic context. However, even Scandinavian philosophers were influenced by the emergence of the pragmatist movement. Thus, this paper examines not the Italian but the Scandinavian reception of early pragmatism, thereby also slightly contributing to the investigation of the influences of American philosophy outside the United States.

While some Finnish philosophers (e.g., Eino Kaila), among their Nordic colleagues, were seriously interested in pragmatism - particularly James's ideas - in the early decades of the twentieth century, I will not discuss the pragmatist influences in Finnish philosophy in any great detail here, as I have written on that topic at some length elsewhere, also in English (Pihlström 2001a, 2001b, 2003b, 2006; see, however, the last substantial section of this paper for some reflections on Kaila). After very brief remarks on the scarce pragmatist currents of thought in Denmark, Iceland, and Estonia, I will focus on pragmatist developments in Sweden and Norway, in order to say a few words on the Finnish situation before my concluding remarks. Needless to say, the general context the history of philosophy in the Nordic countries - cannot be discussed here. (For a general description of the history of Finnish philosophy, see Ilkka Niiniluoto's many writings, e.g., his 2003; cf. Haaparanta \& Niiniluoto 2003 for a collection of papers on the history of analytic philosophy in Finland, including some "classical" texts by Edward Westermarck, Eino Kaila, G.H. von Wright, and Jaakko Hintikka. In Sweden, unlike Finland, even a monographic history of Swedish philosophy has been published: see Lagerlund 2003. However, there is a monograph available on the history of the "philosophy of culture" in Finland in the twentieth century: see Salmela 1998.)

\section{Pragmatism in Iceland, Denmark, and Estonia}

4 There is relatively little to be told about pragmatism in Iceland, except for the very recent work by Jon ólafsson. No major Icelandic philosopher, as far as I know, has been explicitly influenced by the pragmatist classics.

Almost the same appears to be true about Denmark, with the exception of Harald Höffding's and William James's acquaintance, culminating in their mutual exchange of prefaces in the translations of their books (Höffding 1906, James 1906a; cf. Höffding 1915). Much later, a chapter devoted to pragmatism appeared in the comprehensive Danish textbook of contemporary philosophy (Stefanssen 1982).

Höffding and James, however, were contemporaries and were, among other things, interested in the philosophy of religion; yet, it would be an exaggeration to call Höffding a pragmatist (cf. Brown et al. 1996: 344-5). Some of James's books were translated into Danish relatively early, though: The Varieties of Religious Experience (1902) appeared with Höffding's preface in 1906, and Human Immortality (1898) was translated in 1918. Other 
pragmatists were exposed to Danes in the form of translations significantly later: a selection of John Dewey's writings appeared in 1969, and a selection of Peirce's papers in 1988 (Stefanssen 1982: 778-81; Bertilsson \& Christiansen 1990: 11). It may also be noted that Ignas Skrupskelis (1977: 186) lists two Danish contributions by Valdemar Hansen $(1922,1936)$ in his bibliography of literature on William James.

It is to some extent an open question whether Estonia should be classified among the Nordic countries. Be that as it may, again the pragmatist influences have been almost non-existent. Understandably, philosophy in Estonia in the twentieth century focused on the philosophy of science, which was ideologically more neutral than many other fields of philosophy. It might be mentioned, however, that the well-known chemist Wilhelm Ostwald, who was awarded the Nobel Prize in 1909 and to whom James favorably refers when characterizing the pragmatic method in Pragmatism (James 1907: ch. 2), studied and worked at the University of Tartu (Dorpat) from 1872 to 1881 (Vihalemm \& Müürsepp 2007: 171). I am not claiming, of course, that those of his ideas that James later saw as (proto-)pragmatist would have been formed during that period. Moreover, it has been suggested by Rein Vihalemm that Marx's early notion of practice, which Estonian philosophers especially in the 1970s worked on and which was considered heretical in the Soviet Union, might be usefully compared to pragmatism (cf. ibid.: 174).

Because of the scarcity of material on Danish, Icelandic, or Estonian pragmatism, I will next focus on Sweden and Norway. It must be noted, however, that my discussion is primarily a relatively brief bibliographical survey, indicating key persons and central literature that need to be taken into account, if one wants to study the ways in which pragmatism actually landed in Scandinavia. (Helpful bibliographical material can be found in Stefanssen 1987, Brown et al. 1996, and Shook 1998. In some cases I have unfortunately been unable to find the books I cite from the university libraries conveniently at my disposal.) Instead of constituting a genuinely philosophical investigation, my paper thus primarily functions as a (potential) groundwork for later research on this topic. Here I will make no claims to interpreting either the classical pragmatists or their Scandinavian heirs. Furthermore, I can only refer to literature on pragmatism that is primarily philosophical; for example, pedagogical literature on Dewey's educational thought, or theological discussions of James, falls outside the scope of this survey.

\section{Pragmatism in Sweden}

The early spreading of the pragmatist tradition around the world, including Scandinavia, was largely due to the international reputation of James. He had adopted the "pragmatic maxim" from his friend Peirce, but applied it more widely to examine the (conceivable) "practical results" of not just scientific but any humanly important views and ideas, including ethical and religious ones (Pihlström 2004, 2008). It was James's and his followers' (e.g., Schiller's) pragmatism, rather than Peirce's, that was received in the Nordic countries - although James's pragmatism cannot be understood without appreciating its Peircean background.

10 Early Swedish contributions to the reception of pragmatism include Malte Jacobsson's book (1910), as well as Adolf Phalén's (1914: 348-52, 576-7) critical remarks on James's concept of consciousness (see Brown et al. 1996: 615-6). Phalén was interested in James from a psychological perspective, but Jacobsson's (1910) work, presented as a doctoral 
thesis at the University of Lund, is a surprisingly comprehensive critical examination of central issues of James's, Dewey's, and Schiller's pragmatism: e.g., "konsekvensläran" (i.e., the pragmatic principle according to which the concrete practical consequences of thought are what counts); the organic (biological) basis of thought; pragmatic views of categories and concepts, of reality, of "pure experience," and of truth; the relation between logic and psychology; and pragmatist conceptions of religion. The work concludes with a historical sketch of the background of pragmatism, tracing the roots of the tradition to the opposition between Plato and Protagoras. Jacobsson raises a number of objections to pragmatism: it does not follow from the utility of thought that truth amounts to utility (ibid.: 28 and passim); we need "pure" intellectual norms of thought ( ibid.: 70), without which scientific methods cannot be understood (ibid.: 78); pragmatism with its emphasis on personal volition - is at odds with James's and Dewey's views on impersonal "pure experience" (ibid.: 104); logic is not based on psychology (ibid.: 119, ch. 8). He finds a basic opposition between pragmatism and (neo-) Kantian "criticism" something that has more recently been called into question (Pihlström 2003a).

11 Somewhat later, in the 1930-40s, philosopher and sociologist Torgny Segerstedt was influenced by another classical pragmatist, George Herbert Mead (Brown et al. 1996: 714), while Elor Aakesson wrote on James (Aakesson 1934; see Skrupskelis 1977: 183). The Swedes were active in translating James's works: The Will to Believe (1897) appeared in 1908, Human Immortality in the same year, Varieties already in 1906, and Pragmatism (1907) in 1916 - but note that a Finnish translation of this central volume appeared already in 1913 (cf. below)! In addition, a collection by James entitled Människans dolda krafter och andra essayer was published in 1919-1924 (Stefanssen 1982: 781) Again, Peirce was discovered much later: a collection of his essays in Swedish was published in 1990 though significantly earlier than an analogous collection in Finnish.

Perhaps the most important Swedish thinker directly influenced by pragmatism, particularly James's, was Vitalis Norström, whose main influence was Kantianism, though. Norström was in his time a well known Swedish philosopher actively engaged in cultural debates. Jacobsson (1910: 189) also notes that pragmatism in Sweden, "särskilt hos Vitalis Norström," requires a special investigation - and even claims to find pragmatist tendencies in a letter by the romantic writer Esaias Tegnér from 1821 (ibid:: 164). Norström's connection with pragmatism is noted in Henrik Lagerlund's comprehensive survey of the history of Swedish philosophy (Lagerlund 2003: 146-8). In particular, Norström's 1899 essay, "Hvad är sanningen?," comes close to Jamesian ideas on truth, rejecting the view that truth - in science or elsewhere - would just be a representation of reality. The scientific picture of the world is not a "photography of reality" ("verklighetsfotografi") (cit. Lagerlund 2003: 147), but an instrument for serving our cultural interests. Lagerlund observes that Norström, by relativizing and pragmaticing the notion of truth, attempts to make room for a spiritual dimension in reality (ibid:: 148), which is pretty much what James himself attempted as well.

Post-World-War-II Swedish contributions to pragmatism include, most significantly, Hjalmar Wennerberg's dissertation on Peirce in 1962 and his later book (Wennerberg 1966), in which he defended the traditional interpretation that James's pragmatism was to a large extent a misunderstanding of Peirce's. Also, Lars Boman (1955) referred to James frequently, while focusing on American "new realism" instead of pragmatism. Later, James was studied from the point of view of the psychology of religion in essays collected in Pettersson \& Åkerberg (1980). The translation anthology of Peirce's papers 
contains a useful introduction (Bertilsson \& Christiansen 1990), based on Swedish-Danish cooperation.

It is also worth observing that John Elof Boodin, a noteworthy but somewhat neglected American philosopher who contributed to discussions of pragmatism, realism, and emergentism (among other issues) during the first half of the twentieth century, was born in 1869 in Pjetteryd, Southern Sweden (Brown et al. 1996: 86). He is mentioned in Shook's (1998: xiii) introduction to the bibliography of pragmatism as one of the twelve "major figures" of pragmatism (his main works in metaphysics and epistemology include Boodin 1911 and 1916). Perhaps we cannot classify him among Scandinavian philosophers, because he received his academic education in American universities and created his career in the United States; he emigrated in 1887, after having received his primary education in Sweden. Boodin (1930) describes his Swedish background at some length in an autobiographical essay, speculating that his work and training on his home farm with intimate contact with nature may have made him an "empirical realist." He also mentions that his first encounter with William James took place in 1896 at Brown University Philosophical Society (ibid.: 138), a year before he entered Harvard University.

Boodin's comment on his relation to pragmatism may be quoted at length, because it might sound familiar to other "sympathetic interpreters" of pragmatism as well:

I ought, perhaps, to say something about my relation to pragmatism; but I own that I feel a strong repugnance to doing so. For I meant to do a generous thing and received only misunderstanding as my reward. [...] [P]ragmatism was attacked on all sides and the debate only led to more confusion, so I thought I would try the method of sympathetic interpretation. Pragmatism certainly claimed to be a rediscovery of everything that is sane, and I tried to view it in that light. [...] I have at any rate the satisfaction that if I did not please the pragmatists I did not sacrifice truth as I saw it. Whether I had any influence in turning pragmatism into a more realistic direction, I do not know. (Ibid.: 139-40)

16 He adds that pragmatism "is now dead, and it is not seemly to speak ill of the dead" (ibid.: 140). Yet, while the movement seemed to be dead in 1930, Boodin argues that a pragmatic attitude to inquiry and the pursuit of truth is worth maintaining: 'Pragmatic' emphasizes [...] the convenience of an hypothesis in dealing with the emergencies of experience. Truth as we have it is never an exact picture of the nature of things, but it enables us to proceed in the direction of further acquaintance with reality. [...] Long live pragmatism!" (ibid.: 140-1).

\section{Pragmatism in Norway}

17 Turning from Sweden to the neighboring Norway, we find significantly less pragmatist influences, and the ones we do find are primarily connected with later "Continental" streams of thought rather than being immediate responses to the classical pragmatists' views.

Arne Naess was without doubt the best known Norwegian philosopher of the twentieth century. He wrote hardly anything on pragmatism (as far as I know), but his pupil Ingemund Gullvåg did write on Peirce in the 1960s and published selected translations of Peirce's writings in 1972 (Bertilsson \& Christiansen 1990: 11; see Gullvåg 1981 for a comparison between Peirce and Wittgenstein). Peter Skagestad became an internationally distinguished Peirce scholar somewhat later (Skagestad 1981). Hans Skjervheim, a 
hermeneuticist and a critic of Naess, also referred to pragmatism, though not in scholarly detail, in the 1950-60s (Skjervheim 1959; Brown et al. 1996: 728-9). Roughly at the same time, Ragnar Rommetveit (a psychologist rather than a philosopher) studied Mead. (Torjus Midtgarden, personal communication, January 5, 2004.) So, pragmatism was not entirely forgotten, but people really interested in this tradition were few, and their major concerns (probably with the exception of Skagestad) were usually outside pragmatism scholarship proper.

Later, the Norwegian absorption of pragmatism has taken place largely under the spell of a number of Norwegian philosophers' works on Karl-Otto Apel's and Jürgen Habermas's transcendental pragmatics and discourse ethics, often in comparison with parallel ideas in Wittgenstein's philosophy of language-games (see the papers in Böhler et al. 1986; Høibraaten \& Gullvåg 1985-1990; especially Skirbekk 1985). Except for discussions of Apel's interpretation and appropriation of Peirce in the 1970s (which brought Peirce and pragmatism into the consciousness of German-speaking philosophers in Europe), no substantial connection to the pragmatist tradition can be found in these writings by Norwegian thinkers. Accordingly, we should perhaps speak about the reception of (transcendental) pragmatics instead of pragmatism in this case.

However, as the relation between the Kantian tradition of transcendental philosophy and the apparently very different tradition of pragmatism is being re-evaluated (Pihlström 2003a), these Norwegian contributions to the integration of pragmatism and transcendentalism, though somewhat far removed from actual pragmatism scholarship, do deserve serious investigation.

\section{Pragmatism in Finland}

21 As already noted, several Finnish philosophers wrote on pragmatism in the early decades of its influence. Eino Kaila, to be commented on below, was the best-known among them, but already his father, Erkki Kaila, who later became the arch-bishop of the Finnish Lutheran church, was familiar with James's religious thought (see his 1911: 285-7; 1914). Young Finnish thinkers, Allan Törnudd and J. W. Snellman (the grandson of the "National philosopher" J.V.Snellman), who never created an academic careers in philosophy, published international articles on James's and Schiller's pragmatist views on truth, thus modestly contributing to the debate over pragmatism that was going on early in the twentieth century. These commentators were sympathetic to pragmatism, attempting to defend James (and Schiller) against realist criticism, e.g., Bertrand Russell's (see Snellman 1911, Törnudd 1915). Also, in the meetings of the Philosophical Society of Finland, which had been founded by Thiodolf Rein in 1873, pragmatism was one of the major topics in the 1910s, especially 1912 and shortly thereafter, with presentations by Törnudd, Snellman, and some other younger philosophers, and (usually critical) comments by the older philosophical establishment, including Rein and Arvi Grotenfelt (see Manninen \& Niiniluoto 1996, especially 399-405). In the 1920-30s, James's and Dewey's pragmatisms were aggressively attacked by J. E. Salomaa, who saw pragmatism as an enemy of culture and spirit (see Salomaa 1924, 1930).

Later, Kaila's pupils G.H. von Wright and Oiva Ketonen referred to the classical pragmatists in some of their writings, and Ketonen may be described as a Deweyan naturalist (see Ketonen 1954: 1981; Pihlström 2001b). From von Wright's (1943) perspective, Peirce and James were primarily precursors of logical empiricism. In any 
event, none of the leading analytic philosophers in Finland - von Wright, Ketonen, Erik Stenius, Jaakko Hintikka, Raimo Tuomela, Ilkka Niiniluoto - can be characterized as a pragmatist, though Hintikka served as the president of the Charles S. Peirce Society in the 1990s. The same translator has recently (2010) completed the Finnish edition of Dewey's Art as Experience.

James's pragmatism was relatively well received in Finland immediately after James's death. Several translations were published, including Pragmatism in 1913, The Varieties of Religious Experience in 1914, Talks to Teachers in 1916, and Human Immortality in 1922. (Dewey's School and Society was translated into Finnish in 1957; the next Finnish translations of his work were The Quest for Certainty in 1999 and Public and Its Problems in 2006. Again, Peirce was the one almost forgotten in the early days; the only collection of his writings available in Finnish was published in 2001.) It might also be mentioned that a brand new Finnish translation of James's Pragmatism, by Antti Immonen, came out in 2008.

The most important Finnish thinker influenced by pragmatism, especially James, was thus undoubtedly Eino Kaila. After his early enthusiasm about James's pragmatism and the "will to believe" doctrine (see Kaila 1912), Kaila's logical empiricist thought matured, but a version of pragmatism can still be found - or at least reconstructed - in his views on the "practical testability" of metaphysical, religious, and other weltanschaulich ideas. In his logical empiricist philosophy of science, Kaila defended a "principle of testability" according to which any meaningful statement about reality must be constructed in such a way that a set of empirical statements - its "real content" - can be derived from it. Metaphysical statements fail to meet this requirement, just as Rudolf Carnap and other logical empiricists had argued. However, Kaila was a thinker tormented by diverging intellectual interests, and he also wanted to make room for metaphysical ideas. He suggested that metaphysical and religious concepts may be "practically tested." In his psychological work, Persoonallisuus (1934: 365), he describes religions as "spiritual insurance companies" defending us against the threats of life, especially our fear of death.

Kaila's conception of the pragmatic value of religious ideas and ideals may be fruitfully compared to Dewey's account of religion, as formulated in A Common Faith (1934). For both, it is vitally important to distinguish between religious qualities of experience (religiosity), on the one hand, and the actual historical religions, on the other. Religions, with their supernaturalist dogmas, may not serve but may actually hinder the realization of religious values in experience. For Kaila, "deep-mental" life is the most important goal of human existence, and it can to some extent be actualized in a religious context, though science and art are also among the key practices within which deep-mentality is possible. Kaila's defense of deep-mentality resembles Dewey's defense of a non-dogmatic, nonsupernaturalist (fully naturalized) account of the religious dimensions of experience. For both, a distinction between religions and religiosity is crucial. Religiosity is, according to Kaila, the "deep-mental" core of religions; mental life, in turn, can be said to be deepmental when the "depth dimension" of an emotion reaches its maximum, that is, when its object, some value, is regarded as "sacred" (Kaila 1934: 364-5; cf. p. 239).

In his later dialogical work, Syvähenkinen elämä (1943), Kaila argues that even though the "real content" of religious and metaphysical views is very small, such Weltanschauungen may be practically significant. What he calls practical testability has nothing to do with the real content of beliefs or statements but their results in a human being's practical 
action and way of life. Religion and metaphysics are practically testable in terms of their serving as motives for action; they may be accepted insofar as their practical results are acceptable (Kaila 1986, 188-9). Religions must be rejected as systems of (supernatural) beliefs, just as Dewey rejected them, but as "systems of action" they may be acceptable. This "practical truth," Kaila says, is however to be distinguished from "truth in the proper theoretical sense" (ibid.: 189). Kaila explicitly mentions James as a background figure for these views (ibid.: 8, 202); also, his war-time diary entries in 1941-43 demonstrate that he was thinking about James while working on Syvähenkinen elämä. What is more, Kaila's less scientific, more "romantic" and metaphysical voice in the dialogues of the book speculates that theoretical and practical testability might ultimately collapse into one another (ibid.: 192), which is clearly something that Jamesian pragmatists might easily subscribe to. Kaila's reaction to James, and his way of developing an interpretation of religion (and metaphysics) that may be compared to Dewey's, offer original insights into fundamental issues of pragmatism. Later Finnish commentators have only rarely reached this level of sophistication in their discussions of pragmatism. While Kaila never fully became a pragmatist, he was an independent thinker preoccupied with the kind of questions, especially the tension between science and (religious) metaphysics, that the great classical pragmatists examined.

\section{Concluding Remarks}

27 Clearly, pragmatism has not been a major philosophical movement in any of the Nordic countries. Its early developments were noted by Scandinavian scholars, and several translations were published; however, as other traditions - especially logical empiricism and analytic philosophy - started to flourish before World War II and occupied a central place on the philosophical scene after the war, pragmatism rapidly declined. This happened both in the homeland of pragmatism, the United States, and in the European countries to which the movement had spread through the lively interest in James and Schiller. In most Scandinavian countries (and elsewhere), pragmatism was seen as a precursor of logical empiricism, though too informal and loose to be taken seriously by a truly scientific philosopher.

Only later, after the new rise of pragmatism as the heterogeneous and controversial "neopragmatist" movement, associated with leading American philosophers such as Richard Rorty and Hilary Putnam, have new works on pragmatism again been widely published in the Nordic countries (and, of course, elsewhere). Nowadays, scholars like Bjørn Ramberg and Torjus Midtgarden in Norway, or Leila Haaparanta, Erkki Kilpinen, and AhtiVeikko Pietarinen in Finland, belong to the internationally active (and growing) group of philosophers working on pragmatism or themes related to it. Also, historical interest in the development of pragmatism has become stronger. In Finland, Pentti Määttänen (1993) has employed Peircean insights in the philosophy of mind and theory of action, Erkki Kilpinen (2000) has studied pragmatist social theory, and Mats Bergman (2004) has investigated Peirce's semiotics in close historical detail, while Pietarinen (2007) has applied Peircean ideas in logic. The first Finnish collection of articles entirely devoted to pragmatism was recently published (Kilpinen et al. 2008). In Sweden, Ulf Zackariasson (2002) wrote a dissertation on pragmatist philosophy of religion, and the pragmatist perspective in that field has been defended in several publications by Eberhard Herrmann (e.g., 2003). Thus, at least these key topics of pragmatist philosophers - social theory, 
communication, religion - are well and alive in Scandinavia. Philosophy of science has not been forgotten, either, as Ilkka Niiniluoto's (1999) defense of "critical scientific realism" is to a large extent Peircean (on the issue of scientific realism in a pragmatist context, see, however, Pihlström 1996). Also, dissertations and other works on Rorty's radical neopragmatism have been and are being written. Ramberg is one of the leading expert on Rorty's philosophy, including its connections with Davidson (see Ramberg 2000).

Instead of analyzing these recent developments in any detail I want to conclude by a brief note on two early Scandinavian philosophers who may be regarded as the greatest Nordic precursors or background figures of pragmatism: Søren Kierkegaard and (perhaps more surprisingly) Emanuel Swedenborg. James seems to have respected Kierkegaard, the "Danish thinker," as a deep religious philosopher and even as a kind of a protopragmatist. He actually found the Kierkegaard quote, "[w]e live forwards [...] but we understand backwards" (James 1907: 107; 1912: 238) from the writings of another Dane, Höffding (see the editors' notes to this phrase at James 1907: 161; cf. Deuser 2000: 193-5). Swedenborg's influence on James was also primarily indirect, transmitted through William's father Henry James, Sr., who was a "Swedenborgian." (This aspect of William James's thought has also been studied in Finland: see Värilä 1977.)

Obviously, neither Kierkegaard nor Swedenborg can be labeled a "Scandinavian pragmatist," but both are Nordic thinkers who had an important influence on at least some members of the pragmatist tradition, especially James. Thus, the Scandinavian contribution to pragmatism should also be studied in relation to these early Nordic classics. The subject index to Shook's (1998) bibliography of pragmatism lists, however, only a few references to Swedenborg in pragmatist writings between 1898 and 1940 - and none to Kierkegaard. The explanation for this may be that the bibliography, just like the majority of works on pragmatism, neglects the Scandinavian languages and lists (mainly) works in English, German, French, and Italian. It is only fair, however, that Jacobsson (1910: 164-5), in the first Scandinavian book-length study on pragmatism, also lets Kierkegaard's voice to be heard - though only in passing.

\section{BIBLIOGRAPHY}

AAKESSON Elof, (1934), “Begreppet 'medvetande' i William James' radikala empirism," in Gåva och krav: skrifter tillägnade Manfred Björkquist på hans femtioårsdag den 22 juni 1934, Uppsala, Almquist \& Wiksell.

BERGMAn Mats, (2004), Fields of Signification: Explorations in Charles S. Peirce's Theory of Signs, Philosophical Studies from the University of Helsinki 6, Department of Philosophy, Helsinki, University of Helsinki.

BERTILSSON Margareta \& Peder Voetmann CHRISTIANSEN, (1990), "Inledning: Charles Sanders Peirce (1839-1914)," in Charles Sanders Peirce, Pragmatism och kosmologi, Swedish trans. Richard Matz, Göteborg, Daidalos, 7-36. 
BLOMBERG Jaakko, (1969), “James on Belief and Truth," Ajatus 31, 171-87.

Boman Lars, (1955), Criticism and Constructivism in the Philosophy of the American New Realism, Stockholm, Almqvist \& Wiksell.

BooDIN John E., (1911), Truth and Reality: An Introduction to the Theory of Knowledge, New York, Macmillan.

Boodin John E., (1916), A Realistic Universe: An Introduction to Metaphysics, New York, Macmillan, (2nd ed. 1931).

BoodiN John E., (1930), "Nature and Reason," in George P. Adams \& Wm. Pepperell Montague (eds.), Contemporary American Philosophy: Personal Statements, vol. I, New York, Macmillan, 135-66. BROWN Stuart, COLLINSON Diané \& Robert WILKINSON (eds.), (1996), Biographical Dictionary of Twentieth-Century Philosophers, London \& New York, Routledge, 2002.

BÖHLER Dietrich, NORDENSTAM Tore \& Gunnar SKIRBEKK, (eds.) (1986), Die pragmatische Wende: Sprachspielpragmatik oder Transzendentalpragmatik?, Frankfurt am Main, Suhrkamp.

colella E. Paul, (2005), "Reflex Action and the Pragmatism of Giovanni Papini," Journal of Speculative Philosophy 19, 187-215.

DEUSER Hermann, (2000), “Zur Achten Vorlesung (I): Pragmatismus und Religion," in Klaus Oehler (ed.), William James: Pragmatismus, Berlin, Akademie Verlag, 185-212.

DEWEY John, (1934), A Common Faith, New Haven, CT \& London, Yale University Press, 1991.

GoLINo Carlo L., (1955), “Giovanni Papini and American Pragmatism,” Italica 32, 38-48.

GULLACE Giovanni, (1962), “The Pragmatist Movement in Italy,” Journal of the History of Ideas 23, 91-105.

GULLVÅG Ingemund, (1981), “Wittgenstein and Peirce," in K. S. Johannesen \& T. Nordenstam (eds.), Wittgenstein - Aesthetics and Transcendental Philosophy, Vienna, Hölder-Pichler-Tempsky, 70-85.

HAAPARANTA Leila, (1994), “Charles Peirce and the Drawings of the Mind," Histoire Epistemologie Langage 16/I, 35-52.

HAAPARANTA Leila \& Ilkka Ninniluoto (eds.), (2003), 'Analytic Philosophy in Finland,' Poznan Studies in the Philosophy of the Sciences and the Humanities 80, Amsterdam \& New York, Rodopi.

HANSEN Valdemar, (1922), “William James og hans breve,” Nordisk Tidskrift för Vetenskap, konst och industri, 176-84.

HANSEN Valdemar, (1936), William James og det religiose, København, C.A. Reitzels Forlag. HERRMANN Eberhard, (2003), “A Pragmatic Realist Philosophy of Religion,” Ars Disputandi, [ tandfonline.com/doi/abs/10.1080/15665399.2003.10819765].

HÖFFDING Harald, (1906), "Preface," in William James, Religiose Erfaringer, Danish trans. E. Lehmann \& C. Monster, København, T. Branner.

HÖFFDING Harald, (1915), Modern Philosophers and Lectures on Bergson, trans. Alfred C. Mason, London, Macmillan.

HøIBRAATEN Helge \& Ingemund GULLVÅG (eds.), (1985-1990), Essays in Pragmatic Philosophy I-II, Oslo, Norwegian University Press.

JACOBSsON Malte, (1910), Pragmatismen: särskilt i dess förhållande till kriticismen, Lund, Berlingska boktryckeriet. 
JAMEs William, (1906a), "Preface," in Harald Höffding, The Problems of Philosophy, trans. G.M. Fisher, New York, Macmillan, v-xiv.

JAMES William, (1906b), "G. Papini and the Pragmatist Movement in Italy," The Journal of Philosophy, Psychology and Scientific Methods 3, 337-41.

JAMES William, (1907), Pragmatism: A New Name for Some Old Ways of Thinking, eds. F. Bowers, F. H. Burkhardt \& I. K. Skrupskelis, Cambridge, MA \& London, Harvard University Press, 1975.

JAMES William, (1912), Essays in Radical Empiricism, ed. Ralph Barton Perry, Lincoln \& London, University of Nebraska Press, 1996.

KAILA Eino, (1912), “William James: Amerikan filosofi” [William James: The Philosopher of America], in Kaila 1990, 80-92.

KAILA Eino, (1934), Persoonallisuus [Personality], Otava, Helsinki. (3rd ed. 1946, reprinted in an abridged form in Kaila 1990.)

KAILA Eino, (1979), Reality and Experience: Four Philosophical Essays, ed. Robert S. Cohen, Dordrecht, D. Reidel.

KAILA Eino, (1986), Syvähenkinen elämä: Keskusteluja viimeisistä kysymyksistä [DeepMental Life: Discussions of Ultimate Questions], Otava, Helsinki, 3rd ed. (1st ed. 1943, in an abridged form in Kaila 1992.)

KAILA Eino, (1990), Valitut teokset 1: 1910-1935 [Selected Works 1: 1910-1935], ed. Ilkka Niiniluoto, Helsinki, Otava.

KAILA Eino, (1992), Valitut teokset 2: 1936-1958 [Selected Works 2: 1936-1958], ed. Ilkka Niiniluoto, Helsinki, Otava.

KAILA Erkki, (1911), Oppikirja uuden ajan filosofian historiassa [A Text-Book in the History of Modern Philosophy], Gummerus, Jyväskylä, 2nd ed.

KAILA Erkki, (1914), Postscript to the Finnish translation (by H. Leiviskä) of William James, The Varieties of Religious Experience: Uskonnollinen kokemus moninaisuudessaan, Gummerus, Jyväskylä. KETONEN Oiva, (1954), “John Dewey 1859-1952,” Ajatus 18, 85-98.

KETONEN Oiva, (1981), Eurooppalaisen ihmisen maailmankatsomus [The World-View of the European Person], Porvoo, WSOY, 3rd ed. (1st ed. 1961.)

KILPINEN Erkki, (2000), The Enormous Fly-Wheel of Society: Pragmatism's Habitual Conception of Rationality and Social Theory, Research Reports 235, Department of Sociology, Helsinki, University of Helsinki.

KILPINEN Erkki, KIVINEN Osmo \& Sami PIHLSTRÖM (eds.), (2008), Pragmatismi filosofiassa ja yhteiskuntatieteessä [Pragmatism in Philosophy and Social Science], Helsinki, Gaudeamus, forthcoming.

KUPI Heikki, (1998), F.C.S. Schillerin pragmatismi: Humanismi maailmankatsomuksena [The Pragmatism of F.C.S. Schiller: Humanism as a World-View], Reports from the Department of Philosophy, Helsinki, University of Helsinki 1/1998.

LAGERLUND Henrik, (2003), Filosofi i Sverige under tusen år, Studentlitteratur, Lund. Manninen Juha \& Niiniluoto Ilkka (eds.) (1996), Ajatuksen laboratorio: Filosofisen Yhdistyksen pöytäkirjat 1873 - 1925 [ The Laboratory of Thought: The Minutes of the Philosophical Society, 1873 - 1925], Helsinki, Suomen Filosofinen Yhdistys. 
MÄÄTTÄNEN Pentti, (1993), Action and Experience: A Naturalistic Approach to Cognition, Annales Academiae Scientarum Fennicae B 64, Helsinki.

NIINILUOTo Ilkka, (1999), Critical Scientific Realism, Oxford \& New York, Oxford University Press. NIINILUoтo Ilkka, (2003), "Philosophy in Finland - The Cultural Setting," in Haaparanta \& Niiniluoto, 11-41.

NORSTRÖM Vitalis, (1899), “Hvad är sanningen?” [“What Is Truth?”], is reprinted in Norström, Tankelinier [Lines of Thought], Stockholm, Hierros, 1905.

PETTERSSON Olof \& Hans ÅKERBERG (eds.), (1980), William James då och nu: Några religionspsykologiska studier, Lund, Doxa.

PHALÉN Adolf, (1914), Zur Bestimmung des Begriffs des Psychischen, Skrifter utgifna af Kungliga Humanistiska Vetenskaps-samfundet i Uppsala 16, Uppsala, Almqvist \& Wiksell.

PIETARINEN Ahti-Veikko, (2007), Signs of Logic, Dordrecht, Springer.

PIHLSTRÖM Sami, (1996), "Structuring the World: The Issue of Realism and the Nature of Ontological Problems in Classical and Contemporary Pragmatism," Acta Philosophica Fennica 59, Helsinki, The Philosophical Society of Finland.

PIHLSTRÖM Sami, (2001a), Filosofin käytännöt: Pragmatismin perinteen vaikutus suomalai-sessa filosofiassa 1900-luvulla [The Philosopher's Practices: The Influences of the Pragmatist Tradition in Finnish Philosophy in the Twentieth Century], Kuopio \& Joensuu, UNIPress.

PIHLSTRÖM Sami, (2001b), “Oiva Ketosen pragmatismija naturalismivaikutteista” [On Oiva Ketonen's Pragmatist and Naturalist Influences], Ajatus 59, 27-44.

PIHLSTRÖM Sami, (2003a), Naturalizing the Transcendental: A Pragmatic View, Amherst, NY, Prometheus/Humanity Books.

PIHLSTRÖM Sami, (2003b), "Pragmatistic Influences in Twentieth Century Finnish Philosophy: From Pre-Analytic to Post-Analytic Thought," in Haaparanta \& Niiniluoto, 511-35.

PIHLSTRÖM Sami, (2004), "Peirce's Place in the Pragmatist Tradition," in Cheryl Misak (ed.), The Cambridge Companion to Peirce, Cambridge, Cambridge University Press, 27- 57.

PIHLSTRÖM Sami, (2006), "Den tidiga receptionen av pragmatismen i Finland och Sverige" [The Early Reception of Pragmatism in Finland and Sweden], Swedish translation by Nike Parland, in Stefan Nygård \& Johan Strang (eds.), Mellan idealism och analytisk filosofi: Den moderna filosofin i Finland och Sverige 1880 - 1950 [Between Idealism and Analytic Philosophy: Modern Philosophy in Finland and Sweden, 1880 - 1950], Svenska litteratursällskapet i Finland, Helsingfors, \& Atlantis, Stockholm, 111-41. PIHLSTRÖM Sami, (2008), “The Trail of the Human Serpent Is over Everything”: Jamesian Perspectives on Mind, World, and Religion, Lanham, MD, University Press of America (Rowman \& Littlefield Publishing Group).

RAMberg Bjørn, (2000), "Post-Ontological Philosophy of Mind," in Robert B. Brandom (ed.), Rorty and His Critics, MA \& Oxford, Blackwell, Malden.

SALMELA Mikko, (1998), Suomalaisen kulttuurifilosofian vuosisata [A Century of Cultural Philosophy in Finland], Helsinki, Otava.

SALomaA J. E., (1924), Nykyajan filosofeja [Contemporary Philosophers], Porvoo, WSOY.

SALOMAA J. E., (1930), "William Jamesin filosofia: Muutamia ääriviivoja" ["The Philosophy of William James: Some Characteristics"], Ajatus 4, 35-55. 
SHOOK John R., (1998), Pragmatism: An Annotated Bibliography 1898-1940, Amsterdam \& Atlanta, Rodopi.

SKAGESTAD Peter, (1981), The Road of Inquiry: Charles Peirce's Pragmatic Realism, New York, Columbia University Press.

SKIRBEKK Gunnar, (1985), "Pragmatism in Apel and Habermas," in Høibraaten \& Gullvåg, vol. I, $118-44$.

SKJERVHEIM Hans, (1959), Objectivism and the Study of Man, Oslo, Universitetsforlaget.

SKRUPSKELIS gnas K., (1977), William James: A Reference Guide, Boston, G. K. Hall \& Co.

Snellman J.W., (1911), “The 'Meaning' and 'Test' of Truth,” Mind 20, 235-42.

STEFANSSEN Niels Christian, (1982), “Den amerikanska pragmatismen,” in Poul Lübcke (ed.), Vår tids filosofi, Swedish trans. Per Bauhn, Forum, Stockholm, 1987, 401-31, 778-82 (notes).

TÖRNUDD Allan, (1915), "Types of Pragmatist Theory of Truth," The Journal of Philosophy, Psychology and Scientific Method 12, 491-500.

VIHALEMM Rein \& Peeter MÜÜRSEPP, (2007), "Philosophy of Science in Estonia," Journal for General Philosophy of Science 38, 167-91.

VÄRILÄ Armi, (1977), The Swedenborgian Background of William James's Philosophy, Annales Academiae Scientiarum Fennicae, Dissertationes Humanarum Litterarum 12, Helsinki.

WENNERBERG Hjalmar, (1966), Pragmatismen: En filosofisk teori om meningsfullhet och sanning, Stockholm, Rabén \& Sjögren.

VON WRIGHT Georg Henrik, (1943), Den logiska empirismen: En huvudriktning i modern filosofi [Logical Empiricism: A Main Orientation in Modern Philosophy], Helsingfors, Söderströms.

ZACKARIASSON Ulf, (2002), Forces by Which We Live: Religion and Religious Experience in Pragmatic Philosophical Anthropology, Studia Philosophiae Religionis 21, Department of Theology, Uppsala, University of Uppsala.

ZANONI C.P., (1979), "Development of Logical Pragmatism in Italy," Journal of the History of Ideas 40, 603-19.

\section{AUTHOR}

\section{SAMI PIHLSTRÖM}

University of Helsinki, Finland

sai.pihlstrom@helsinki.fi 